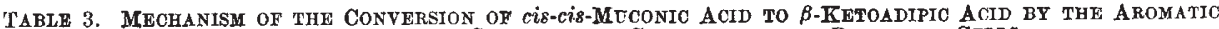
TABLD 3. MEOHANISM OF THE CON<smiles>O=C(O)C1C=CC=C[C@H](C(=O)O)C1</smiles>

I

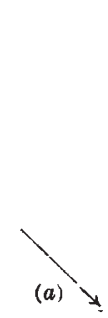<smiles>O=C(O)C1CCC(C(=O)O)C(C(=O)O)C1C(=O)O</smiles><smiles>O=C(O)/C=C\CCCO</smiles>

$\beta$-Ketoadipic acid differs from muconic acid by the elements of a molecule of water. Addition of water to cis-cis-muconic acid would be expected to yield the $\beta$-hydroxy acid which could readily cyclize to the unsaturated lactonic acid, $\gamma$-carboxymethyl- $\Delta^{\alpha}$ butenolide (IV). This has recently been prepared by Elvidge, Linstead, Orkin, Sims, Baer and Pattison ${ }^{19}$. Another related substance at the same level of oxidation and hydration is $\gamma$-carboxymethylenebutanolide $(\mathrm{V})^{20}$. Incubation experiments were accordingly carried out with these unsaturated lactones, $\beta$-ketoadipic acid being tested for by colour reaction and, in some cases, by isolation from the reaction mixtures.

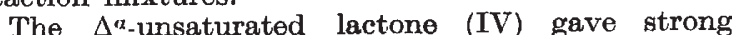
positive results, the isomeride (V) being negative. Table 2 summarizes these experiments, positive signs denoting the extent of appearance of $\beta$-ketoadipic acid. Control experiments on the substrate together with a boiled enzyme solution gave entirely negative results under the same conditions.

In summary, $\gamma$-carboxymethyl- $\Delta^{a}$-butenolide (IV) is converted to $\beta$-ketoadipic acid, appreciably faster than is cis-cis-muconic acid, which is, in turn, faster than catechol. We therefore propose the reaction mechanism given in Table 3 for the missing stages in the total process.

The essential stages are $(a)$ addition of water or isomerization; (b) migration of the double bond; (c) ketonization of the enol corresponding to the $\beta \gamma$-unsaturated lactone (VI). We do not know whether the tautomeric change $(b)$ occurs between the openchain hydroxy acids or their lactonic counterparts. The lactone (VI) is as yet unknown, but the overall changes (I) $\rightarrow$ (IV) and (IV) $\rightarrow$ (II) have been realized in purely chemical reactions (see ref. 19 ; also Kuehl, Linstead and Orkin ${ }^{21}$ ), making it highly probable that the scheme is essentially correct.

It is particularly interesting that the $\gamma \delta$-unsaturated lactone $(V)$ is not an intermediate in the biochemical transformation (I) $\rightarrow$ (II), although both of the steps $(\mathrm{I}) \rightarrow(\mathrm{V})^{10}$ and $(\mathrm{V}) \rightarrow(\text { III })^{20}$ have been effected in vitro.

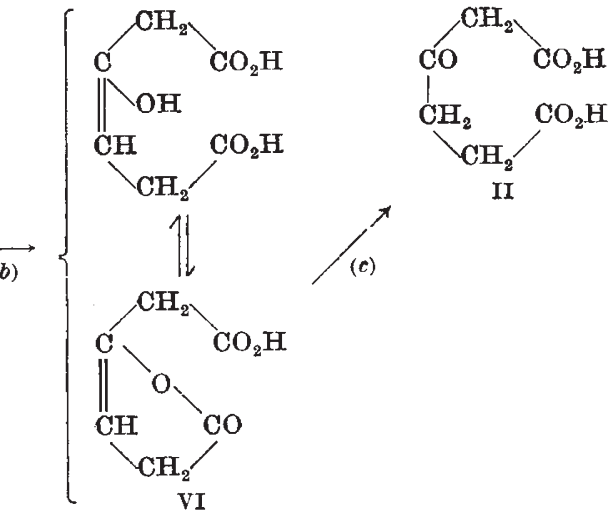

There is a significant difference between the microbiological reactions and the corresponding metabolic processes in mammals. It has long been known that the feeding of benzene leads to the excretion of muconic acid in the trans-trans form. This has recently been carefully confirmed by Parke and Williams ${ }^{22}$. Some process of stereochemical inversion must intervene in the mammalian metabolic processes.

One of us (W. Charles Evans) is grateful to the Royal Society for a grant.

${ }^{1}$ Gray, P. H. H., and Thornton, H. G., Zbl. Bakt., 73, 74 (1928).

${ }^{2}$ ZoBell, C. E., Bact. Rev., 10, 1 (1946); Adv. Enzym., 10, 443 (1950).

${ }^{3}$ Happold, F. C., Biochem. Soc. Symp. No. 5, 85 (1950).

- Evans, W. C., and Fappold, H. C., J. Soc. Chem. Indust., 58, 55 (1939).

${ }^{5}$ Evans, W. C., Biochem. J., 41, 373 (1947).

- Stanier, R. Y., J. Bact., 55, 477 (1948).

Evans, W. C., Parr, W. H., and Evans, R. A., Nature, 164, 674 (1949).

8 Kilby, B. A., Biochem. J., 43, v (1948).

- Evans, W. C., Parr, W. H., and Evans, R. A., Biochem. J., 45, xxx (1949).

${ }^{10}$ Evans, W. C., and Smith, B. S. W., unpublished.

"Suda, M., Hayaishi, O., and Oda, Y., Med. J. Osaka Univ., 2, 21 $(1950)$.

12 Hayaishi, O., and Hashimoto, Z., Med. J. Osaka Univ., 2, 33 (1950).

13 Stanier, R. Y., and Hayaishi, O., private communication (1951).

${ }^{14}$ Elvidge, J. A. Iinstead, R. P., Sims, P., and Orkin, B. A., J. Chem. Soc., 2235 (1950)

ts Böeseken, J., and Engelberts, R., Proc. Acad. Sci., Amsterdam, 34, $292(1931)$; see also ref. 14 .

${ }^{16}$ Elvidge, J. A., Linstead; R. P., and Smith, J. F. (forthcoming publication)

${ }^{17}$ Evans, W. C., and Smith, B. S. W., Biochem. J., 49, x (1951).

18 Stanier, R. Y., J. Bact., 59, 527 (1950).

1. Elvidge, J. A., Linstead, R. P., Orkin, B. A., Sims, P., Baer, H., and Pattison, D. B., J. Chem. Soc., 2228 (1950).

20 Eisner, U., Elvidge, J. A., and Iinstead, R. P., J. Chem. Soc., 2223 (1950).

${ }^{21}$ Kuehl, F. A., Linstead, R. P., and Orkin, B. A., J. Chem. Soc.,

${ }^{22}$ Parke, D. V., and Williams, R. T., Biochem. J., 49, lii (1951).

\section{INSTRUCTIONAL FILM RESEARCH IN PENNSYLVANIA}

THE Pennsylvania State College Instructional 1 Film Research Program, which is still in progress, exceeds in scope any previous research on the instructional film. It was begun in 1947, under the sponsorship of the Special Devices Center of the Office of U.S.A. Naval Kesearch, and is now controlled by a Joint Services Advisory Committee of both the Army and the Navy. These Departments 
are interested in securing improvements in the instructional film, because they use the film for training purposes. They are also anxious to discover how far the film may displace-rather than merely aid-a skilled instructor. But the research-in which a number of divisions of Pennsylvania State College are co-operating - is of a fundamental kind. The results being obtained are of importance to all who use or make educational films.

An account of the work is given in a series of reports issued by the Special Devices Center, Port Washington, N.Y.; application for which can be made to the director of research, Dr. C. R. Carpenter, Pennsylvania State College, U.S.A. (In preparing the present article the reports chiofly consulted were four Technical Reports S.D.C. $269-7-6,9,10,13$; two Progress Reports 11-12, 14-15-16; Incidental Report No. 1; and Special Report No. 2.)

A general method of experimentation has been to produce different versions of a film, and to show them to matched samples of an appropriate audience. Tests, either of the objective multiple-choice question type or of actual performance, are then used to determine the relative teaching effectiveness of the versions. The films used in the experiments have been sound films, predominantly of the commentary. picture type.

Some of the main conclusions so far reached may be characterized as confirming previous opinion. The need for limited and specific objectives in instructional films is much stressed. The rate of development (that is, of putting forward new facts and ideas) of most present-day instructional films is too fast. Good projection and related conditions are of prime importance.

Many of the conclusions are on matters of technique about which, without details of the Pennsylvania experimentation, it would be impossible to form an opinion. In teaching a manipulatory task, the view given should as nearly as possible correspond with that of the learner in performing the task. There is an optimal level for the amount of verbal explanation (found to be about a hundred words a minute for the films used). To establish learning points, commentary should usually be in advance of the picture. The imperative form of address appears the most effective, and the third person passive least effective. There is no advantage in colour, except where it supplies determining learning cues, nor in background music for films of the commentary-picture type. Educational film sessions can last up to one hour with no decrease in etiectiveness of teaching. T'he prestige attached by an audience to the principal exponent in a film increases the influence of the film on attitudes and factual learning from the film. Visual or sound attention-gaining devices, which are themselves irrelevant to the subject-matter, are no advantage.

The most provocative conclusion derived from the experiments is perhaps the one which states that a body of factual information can be taught as well by films alone as by standard lecture - text-book methods. This would seem to imply that films in some circumstances may displace the teacher in the classronm or lecture theatre in a more far-reaching sense than has formerly been realized, and for longer periods. But the Pennsylvania conclusions also make clear that an indispensable part is played by the teacher in 'face-to-face leadership'.

\section{Denis Pegge}

\section{FILARIASIS IN THE PACIFIC}

$\mathrm{W}$ HAT should be regarded as an important step forward in the welfare of the Pacific region and the very varied races that populate its myriad islands has been the creation of a South Pacific Commission with representatives from the widely scattered peoples of this area. The first conference of this newly constituted international body met in Suva during April and May 1950, under the presidency of the Governor of Fiji, Sir Brian Freeston. On the recommendation of this conference a congress in Tahiti of experts on filariasis and elephantiasis was arranged, and met during August 21-September 1, 1951, under the presidency of the Governor of French Oceania in the meeting room of the Representative Assembly at Papeete. Dr. E. Massal, a member of the South Pacific Commission, was elected chairman.

The proceedings of the congress have appeared, with commendable promptitude, in some twentytwo typewritten double-sided sheets. If the nature of the headings and the abstracts of the proceedings are any measure of the labours of this congress, then certainly it must be confessed that an immense amount of work was accomplished. It is gratifying to note that, taking part in the congress and thus adding to its international character, were representatives from Oceania as well as from France, the United States, New Zealand and Australia.

The work of the congress was divided under a number of headings. Under parasitology it was agreed to consider the local filaria as the Pacific variety of Wuchereria bancrofti, as suggested originally by the reviewer, and it was regarded as essential that the minute morphology of the adult stages should be worked out, that studies should be undertaken on the longevity of this parasite and its intermediate immature stages in the human body, and that a review of periodicity throughout the Pacific should be made. Under entomology, a paper on the mosquito vectors of human filariasis in Ocoania was read by Dr. L. Rosen, of the School of Medicine, University of California, paying special attention to the scutellaris group of $A \ddot{e} d e s$ with particular reference to $A$. horrescens. A film on the filariasis control programme in Tahiti was shown. It was further urged that experimental studies on mosquitoes in each area should be made to determine their potentialities as vectors of Wuchereria with special reference to the ability of $W$. bancrofti to develop in culex fatigans in Polynesia and Melanesia. Dr. E. R. R. Brygoo, director of the Institut Pasteur, Saigon, presented a paper on the epidemiology of filariusis in the south Pacific, in which the example of New California was adduced, where neither Anopheles nor the scutellaris group of Aëdes are found, but where filariasis is widespread. The possibility of $W$. malay $i$ being present in New Guinea was raised. The value of intradermal diagnostic tests was discussed, and the result obtained in Tahiti, Fiji and New Caledonia was compared with indefinite results. A new floc. culation test was demonstrated by Dr. W. H. Wright, chief of the Laboratory of Tropical Diseases, Nationel Institutes of Health, Bethesda, United States.

Under the heading of clinical pathology, Dr. P. E. C. Manson-Bahr, physician-specialist, Fiji, read a paper in which he proposed a conception of the infection occurring in three manifestations-primary or allergic, secondary or carrier state, and tertiary or obstructive; and it was agreed that this should form 